\title{
Model Analisis Sistem Pengolahan Limbah Industri Tekstil Menggunakan Bioflokulan Moringa Oleifera Lam.
}

\author{
Ulfah Utami dan Sukarsono
}

Ulfah Utami adalah Dosen Fakultas Sains dan Teknologi UIN Malang, peserta Program Doktor Universitas Brawijaya Malang.

Sukarsono adalah Dosen Jurusan Pendidikan Biologi, Universitas Muhammadiyah Malang

\begin{abstract}
Abstrak
Waste water from textile factories classified into dangerous water as regulated by Ministry of Environment. This waste water usually flow away into the river environment around of factories.

Water treatment unit of textile factory believed as an external unit process which need big budget consequences because it might use imported chemical substances. This situation usually use as a common reasons to pollute the environment.

This research is a model solution to reduce a fix budget (cost production) in textile production by using a number of Moringa oleifera as a biofloculant to replace an expensive chemical substances as PAC. This model showed the number of biofloculant at every target number of production and the impact into amount of sludge and water. Linier model commonly found in every stage of simulation. This research showed what kind of preparation needed by environmental factory manager.
\end{abstract}

Ulul Albab, Vol. 6 No. 1, 2005 


\section{A. Latar Belakang}

Pencemaran lingkungan yang berasal dari proses pengolahan tekstil, dalam ketentuan limbah yang diterbitkan oleh Kantor Menteri Negara Lingkungan Hidup termasuk dalam kategori limbah B3 (Bahan Berbahaya dan Beracun) karena kandungan limbahnya yang dapat membahayakan bagi lingkungan hidup. Sifat bahaya yang diberikan kepada limbah ini menyebabkan setiap usaha pendirian pabrik tekstil (khusus untuk pabrik pencelupan dan pewarnaan) diwajibkan untuk melengkapi fasilitas pabriknya dengan instalasi pengolah limbah.

Namun pada saat ini, data di lapangan menunjukkan bahwa pencemaran lingkungan (terutama sungai) oleh limbah yang berasal dari pabrik pengolahan tekstil tersebut masih terus berlangsung dan cukup sulit untuk dikendalikan. Meski dalam kenyataannya sebuah pabrik memiliki instalasi pengolah limbah, namun biasanya instalasi tersebut sangat jarang atau hampir tidak pernah dipergunakan.

Alasan yang sangat sering disampaikan oleh pemilik maupun pengelola pabrik adalah bahwa biaya pembuatan instalasi terlalu mahal atau kalaupun sudah memiliki instalasi pengolah limbah, alasan yang diberikan adalah biaya operasional pengolahan limbah terlalu mahal (Sukarsono, 1996).

Keinginan untuk meraup keuntungan yang besar dalam waktu yang singkat, kemudian disiasati pengusaha dengan cara mengorbankan lingkungan dan masyarakat disekitarnya baik disadari maupun tidak dan terjadi baik dalam jangka pendek maupun jangka panjang.

Salah satu cara untuk mengurangi beban pencemaran pada limbah cair industri tekstil adalah dengan cara koagulasi dan flokulasi yang berfungsi untuk mengendapkan zat-zaat pencemar dalam air limbah, karena sebagian zat-zat padat yang terdispersi dalam limbah cair industri tekstil merupakan bahan-bahan yang tersuspensi dan sulit untuk mengendap (Reynolds, 1982).

Koagulasi adalah penambahan dan pencampuran suatu koagulan, destabilisasi dari zat-zat koloid padat tersuspensi serta agregasi awal dari partikel terdestabilisasi. Koagulan yang umum digunakan adalah garam alumunium antara lain Poly Aluminium Chlorida (PAC) dan termasuk polimer anorganik dengan berat molekul tinggi, sedangkan flokulasi pada dasarnya adalah pengendapan koloidal akibat pementukan agregat yang lebih lambat dibandingkan dengan koagulasi (Ndaingengsere\&Narasiah, 1995).

Ulul Albab, Vol. 6 No. 1, 2005 
Salah satu upaya yang diberikan untuk mengatasi permasalahan penanganan limbah tekstil tersebut adalah seperti apa yang ditawarkan oleh Rahardjanto, A (1998) dengan menggunakan Moringa oleifera Lam sebagai bioflokulen pengganti $\mathrm{PAC}$ untuk memperbaiki sifat fisiko-kimia air limbah industri tekstil. Bioflokulan ini dapat digunakan dengan alasan bahwa flokulan yang selama ini digunakan oleh pabrik yakni jenis PAC termasuk mahal dan harus di impor, sehingga ketergantungan perusahaan untuk mengolah limbah juga akan sangat dipengaruhi situasi impor.

Temuan penelitian dalam skala pilot dengan teknik yang diusulkan menunjukkan bahwa bioflokulan Moringa oleifera dapat memperbaiki kualitas limbah hingga sesuai dengan baku mutu dan skala pilot ini dapat dilanjutkan ke skala perusahaan. Masalahnya adalah bahwa dalam penerapan skala perusahaan akan sangat dipengaruhi oleh berbagai faktor baik proses maupun manajemen. Pertanyaan tentang faktor-faktor apa sajakah yang harus diperhatikan jika penelitian ini akan diterapkan, menjadi sangat penting untuk dikaji mengingat permasalahan lingkungan tidak pernah dapat ditangani hanya dengan satu sisi melainkan harus dikaji dan ditangani secara bersama dan saling mendukung satu sama lain. Dalam perusahaan, kebijakan satu unit akan sangat mempenaruhi kebijakan unit lain demikian juga dampak kegiatan suatu unit akan berpengaruh terhadap unit lain.

\section{B. Tujuan Penelitian}

Penelitian ini bertujuan untuk :

1. Mengetahui dan mengidentifikasi variabel-variabel yang harus diperhatikan dalam sistem pengolahan limbah dengan menggunakan bioflokulan $M$. oleifera Lam.

2. Menemukan jumlah besaran-besaran tiap variabel yang harus dipenuhi dalam penggunaan bioflokulan M. oleifera Lam.

3. Melakukan simulasi system untuk menemukan sumber masalah sebagai bahan untuk menentukan cara pemecahannya. 


\section{Metode Penelitian}

Penelitian ini dilakukan melalui studi literature dan observasi langsung dengan cara wawancara kepada sample perusahaan yang bergerak dalam bidang tekstil. Studi literatur dilakukan untuk mengkaji hasil-hasil penelitian yang telah dilakukan terhadap limbah pada umumnya dan limbah tekstil khususnya. Literatur juga diperlukan untuk mengkaji interaksi antar komponen dalam system pengolahan limbah dan manajemen perusahaan.

Informasi yang diperoleh selanjutnya dipilah menjadi informasi yang termasuk kedalam level, auxuallary maupun konstanta. Aliran informasi dan komponen sistem ditentukan dan dikaji hubungannya antar satu komponen sistem dengan koponen sistem yang lain.

Pembuatan model dan simulasi dilakukan dengan bantuan computer menggunakan software program analisis system Powersim ModeData US seri 1.03 .

\section{Hasil Dan Pembahasan Penelitian}

\section{Sistem Produksi Tekstil}

Sistem produksi tekstil yang digunakan pada perusahaan mengikuti tahapan sebagai berikut : 


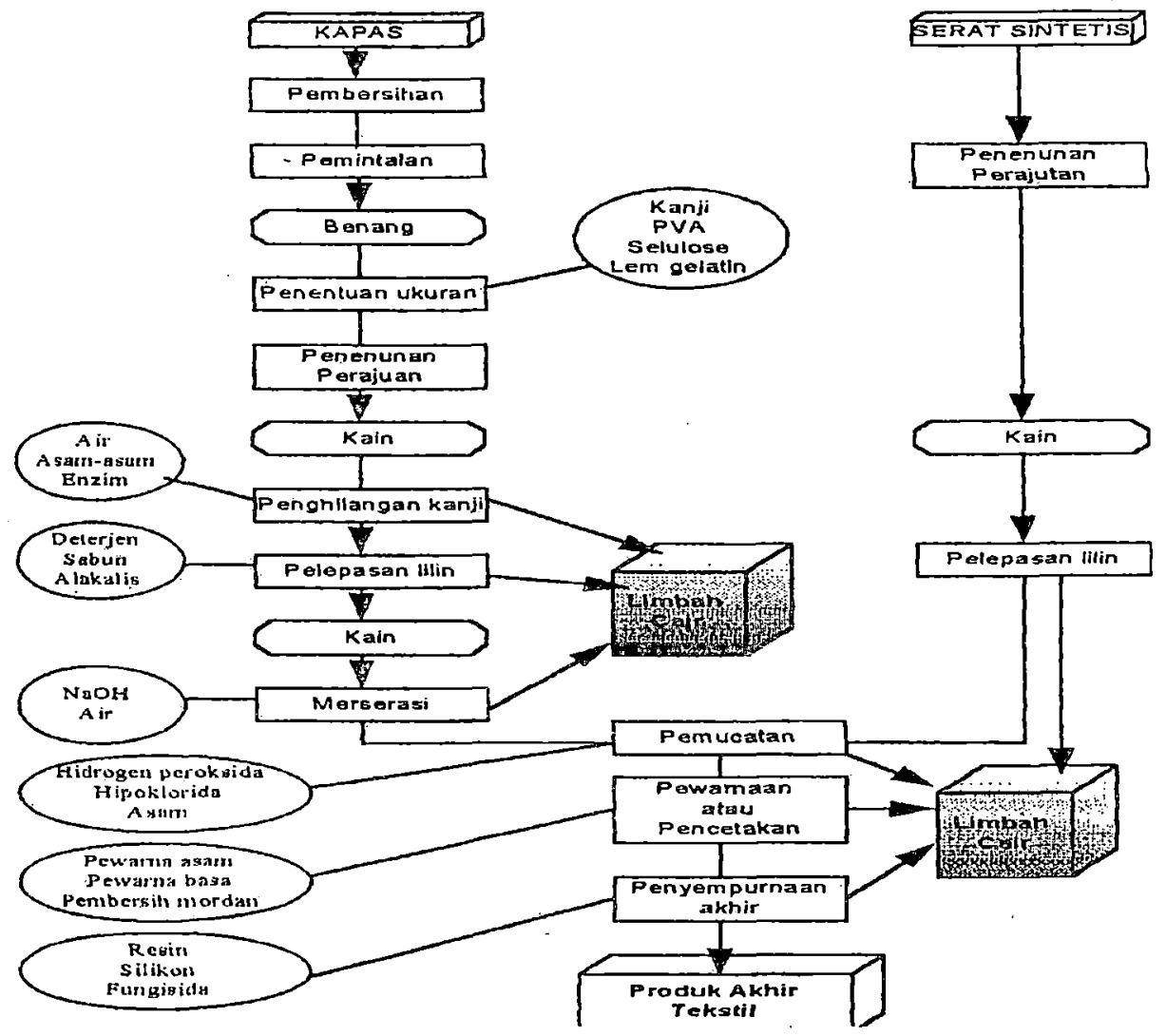

Gambar 1. Bagan Proses Produksi Tekstil dan Limbah yang Dihasilkan

Dari gambar proses produksi terlihat bahwa terdapat dua sumber besar penghasil limbah cair, yakni pada tahap penghilangan kanji, pelepasan lilin dan merserasi. Kegiatan ini menghasilkan limbah paling besar (sekitar $80 \%$ ) yang langsung dibuang ke saluran pembuangan. Tahap berikutnya yang menghasilkan limbah cair besar (sekitar 20\%) dari limbah cair keseluruhan adalah kegiatan pemucatan (bleaching), pewarnaan atau printing dan penyempurnaan akhir.

Enam tahap kegiatan yang menghasilkan limbah cair ini secara keseluruhan memerlukan jumlah air yang sangat besar. Untuk satu kilogram kain yang diproduksi, maka jumlah air yang diperlukan adalah 200 liter. Dengan demikian dapat dibayangkan berapa jumlah air yang diperlukan untuk memproduksi hampir

Ulul Albab, Vol. 6 No. 1, 2005 
1000 kilogram kain. Berapa banyak air yang diambil dari tanah dalam?. Berapa sumur yang harus disediakan jika setiap sumur debitnya diketahui?. Apa yang akan terjadi dengan air penduduk dalam jangka panjang?. Berapa jumlah air yang diperlukan dari waktu ke waktu? dan berbagai pertanyaan lain yang menyangkut faktor produksi, jika pertumbuhan produksi yang dicanangkan oleh perusahaan berjalan dengan baik?

Pertanyaan selanjutnya berkisar pada jumlah limbah dan jumlah M. oleifera Lam yang harus disediakan oleh perusahaan dan bagaimana akumulasi lumpur (sludge) dan logam berat yang akan terjadi jika produksi dilakukan seperti asumsi yang dibuat?. Dan jika pertanyaan berlanjut; berapa jumlah pohon yang harus

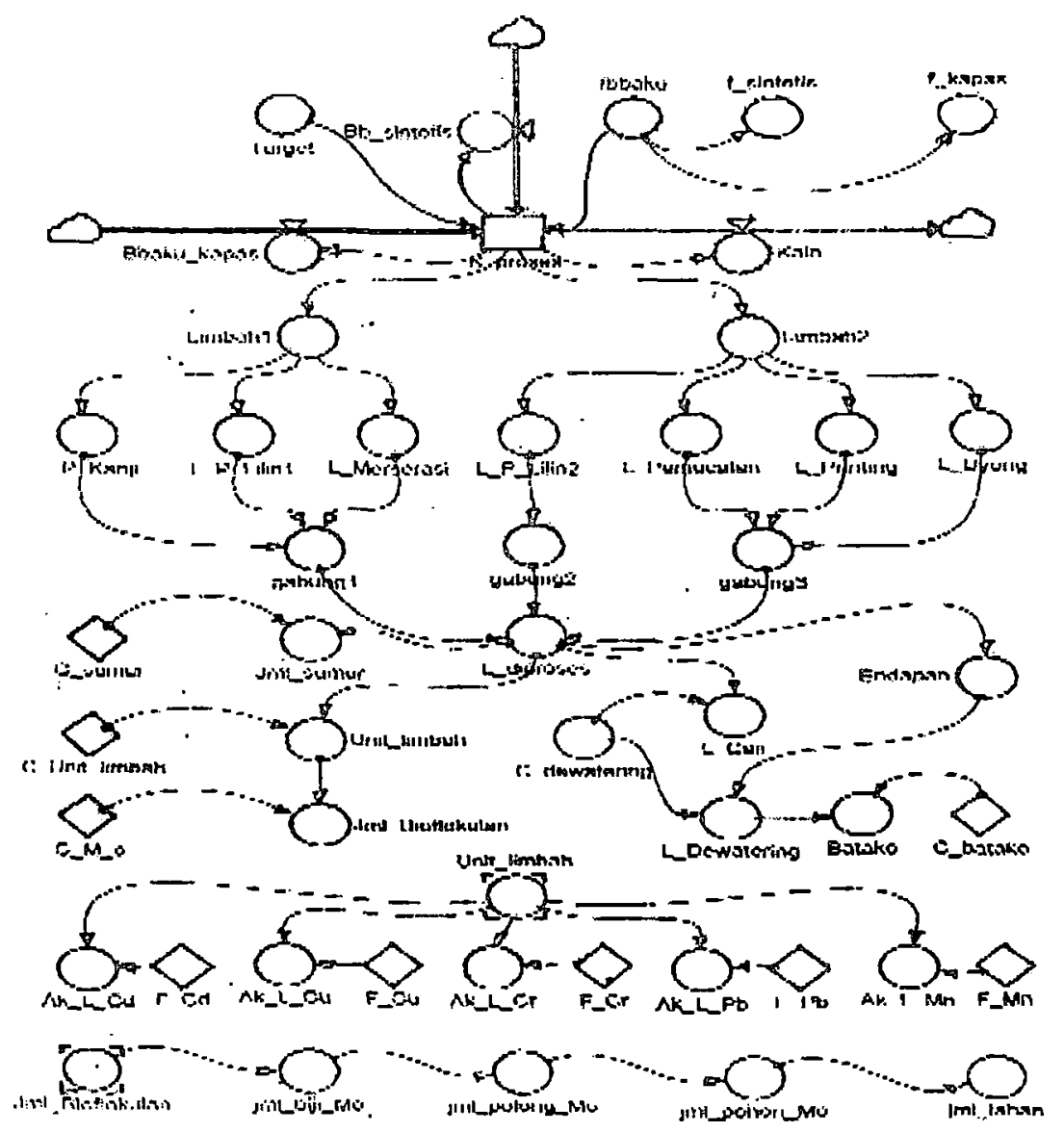

Gambar 2. Diagram Model Analisis Sistem Pengolahan Limbah Pabrik Tekstil

Ulul Albab, Vol. 6 No. 1, 2005 
ditanam dan luasan lahan yang harus disediakan untuk menanam pohon Moringa oleifera tersebut?.

Untuk menjawab berbagai pertanyaan tersebut, berdasarkan survey dan kajian literatur disusun model analisis sistem yang dinamis dan dapat diubah konstanta penyusun model sesuai dengan kondisi yang ada. Diagram analisis sistem tertera pada gambar 1 .

Dalam penelitian ini diambil asumsi pertumbuhan produksi kain yang cukup kecil yakni $0.01 \%$ per bulan, dengan demikian pertumbuhan produksi hanya ditarget sekitar $1 \%$ per tahun. Gambaran pertumbuhan dan kebutuhan bahan baku dalam waktu 24 bulan tertera pada grafik 1.

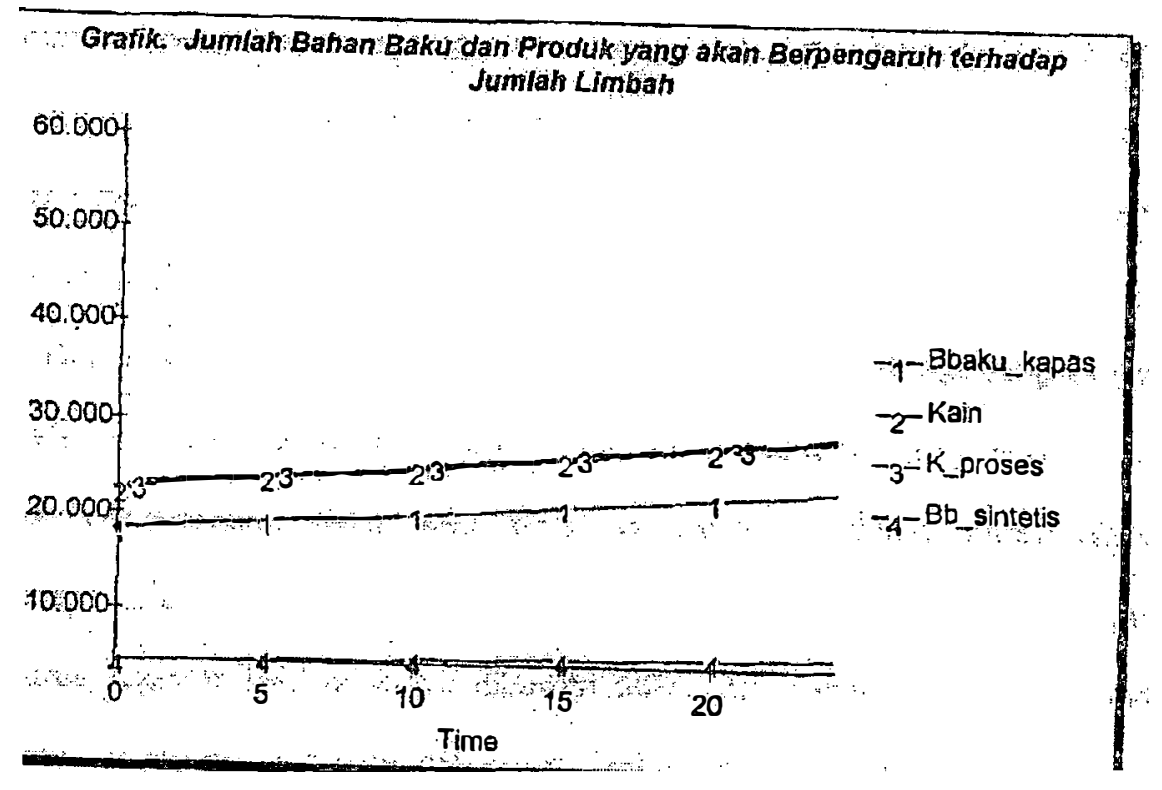

Grafik 1. Jumlah bahan baku yang diperlukan dan produk yang dihasilkan

Dari model analisis sistem pengolahan limbah tersebut akan dapat diprediksi jumlah limbah yang dihasilkan sesuai dengan jumlah bahan baku yang digunakan. Selain itu, dengan target produksi yang ditentukan, dengan menggunakan model tersebut akan dapat dilhat berapa jumlah kain yang dihasilkan, jumlah air yang 
dibutuhkan, debit air yang harus keluar dari dalam tanah, jumlah sumur yang diperlukan, jumlah bioflokulan yang diperlukan, dan sebagainya.

Misalnya, dari running model akan terlihat bahwa jumlah limbah tidak sama besarnya dengan jumlah kain yang diproduksi melainkan lebih besar 200 kali lipat, hal ini terjadi karena setiap kilogram kain yang diproduksi membutuhkan 200 liter air bersih. Sebagai contoh, jumlah limbah yang akan dihasilkan jika menggunakan asumsi pertumbuhan produksi $1 \%$ pertahun dengan jumlah bahan baku tertentu akan dihasilkan limbah sebagaimana tertera pada grafik 2 .

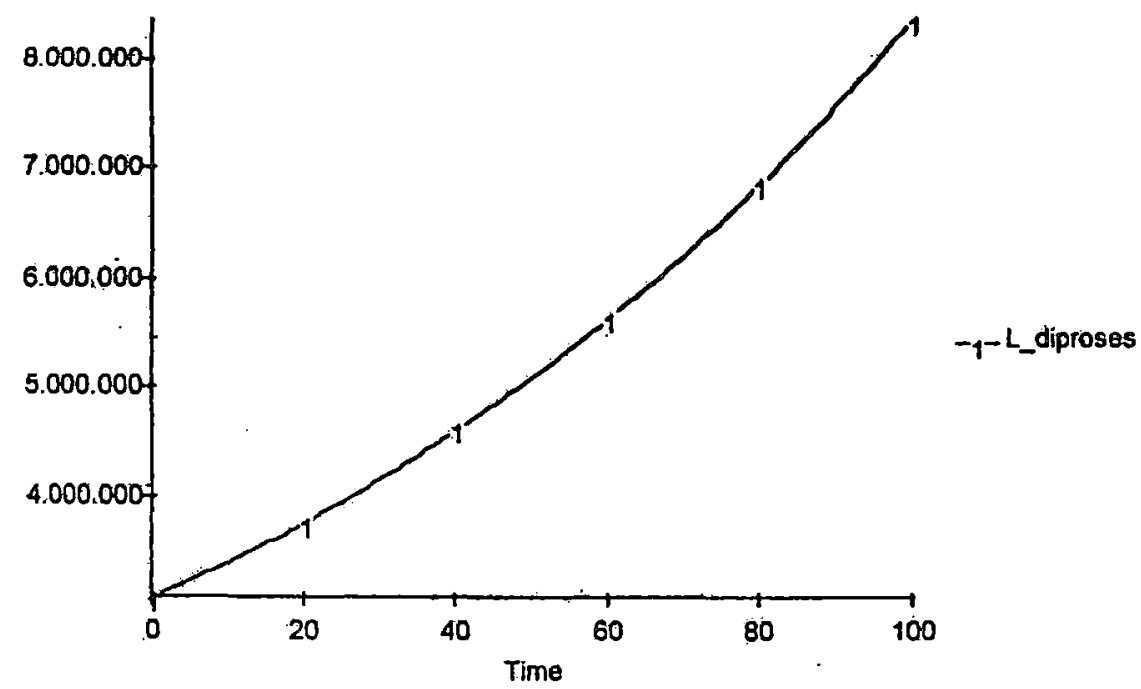

Grafik 2. Jumlah Limbah yang akan Dihasilkan

Sesuai dengan tujuan penelitian, yakni untuk mengkaji sistem pengolahan limbah dengan menggunakan bioflokulan Moringa oleifera, maka jumlah Moringa oleifera yang dibutuhkan dalam bentuk serbuk (satuan gram) sesuai dengan jumlah limbah yang dihasilkan tertera pada gambar grafik 3 . 


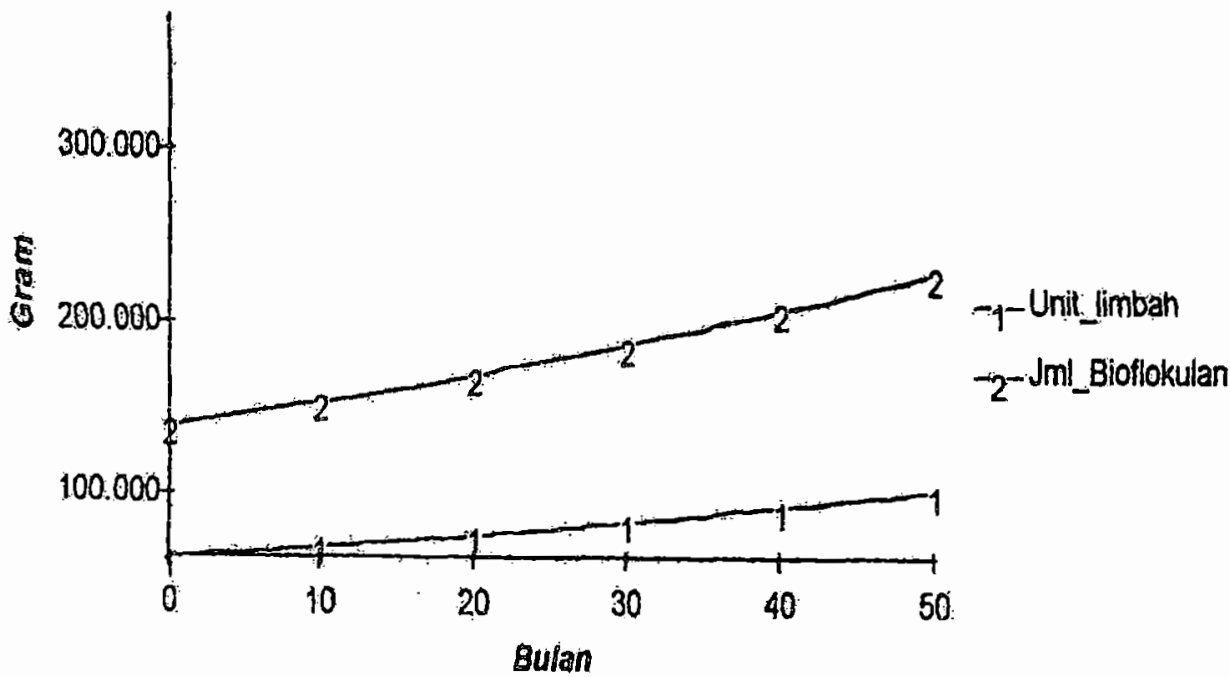

Grafik 3. Jumlah limbah yang dihasilkan dan bioflokulan Moringa oleifera yang dibutuhkan.

Limbah cair yang dihasilkan dari proses produksi selain mengandung air sebaai unsur dominan, juga mengandung padatan tersuspensi (suspended solid) yang cukup tinggi dan tergolong sebagai padatan yang harus dibuang ke tempat aman, salah satunya dibawa ke Pusat Pengolah Limbah Industri B3 di Bogor. Sehingga dengan demikian akan menjadi kesulitan tersendiri bagi perusahaan. Kegiatan dewatering limbah padat ini merupakan cara yang dapat ditempuh dan masih dibenarkan, dan jika limbah padat sudah menumpuk, maka menggunakannya untuk dijadikan bahan baku pembuatan batu bata (batako) adalah hal yang menguntungkan bagi perusahaan karena tidak memerlukan lahan khusus untuk pembuangan dan menhindari pencemaran lingkungan. Jumlah endapan dan batau bata (batako) yang dihasilkan tertera pada tabel berikut: 


\begin{tabular}{|c|c|c|c|c|c|}
\hline TIME & Batako & C_dewatering & Endapan & L Dewatering & \\
\hline 0 & 30,91 & 0,10 & $1.236 .332,80$ & $123.633,28$ & \\
\hline 11 & 31,22 & 0,10 & $1.248 .696,13$ & $124.869,81$ & \\
\hline 2) & 31,53 & 0,10 & $1.261 .183,09$ & $126.118,31:$ & \\
\hline 3 & 31,84 & 0,10 & 1.273 .794 .92 & $127,379,49$ & \\
\hline 4 & 32,16 & 0,10 & $1.286 .532,87$ & $128.653,29$ & \\
\hline 5 & $32,48:$ & 0,10 & $1.299 .398,20$ & $129.939,82$ & \\
\hline 6$]$ & 32,81 & 0,10 & $1.312 .392,18$ & $131,239,22$ & \\
\hline 7) & 33,14 & 0,10 & $1.325 .516,10$ & $132.551,61$ & \\
\hline 8$)$ & 33,47 & 0,10 & $1.339 .771,26$ & $133.877,13$ & \\
\hline 9 & 33,80 & 0,10 & $1.352 .158,98$ & $135.215,90$ & \\
\hline 10 & 34,14 & 0,10 & $1.365 .680,57$ & $\uparrow 35.588,06$ & \\
\hline 11 & 34,48 & 0,10 & $1.379 .337,37$ & $137.933,74$ & \\
\hline 12 & 34,83 & 0.10 & $1.393 .130,74$ & $139.313,07$ & \\
\hline 13 & 3518 & 0,10 & $1.407 .062,05$ & $140.708,21$ & \\
\hline 14 & 35,53 & 0,10 & $1,421,132,67$ & $142.413,27$ & \\
\hline 15 & 35,88 & $0,10^{!}$ & $1.435 .344,00$ & $143.534,40$ & \\
\hline 16 & 36,24 & 0,10 & $1.449 .697,44$ & $144.969,74$ & \\
\hline 17 & 36,60 & 0,10 & $1,464.194,41$ & $146.419,44$ & \\
\hline 19 & 3697 & 010 & 1978836,36 & 14789364 & \\
\hline
\end{tabular}

Konsentrasi logam berat Cadmium (Cd), Chrom (Cr), Cuprum (Cu), Mangan $(\mathrm{Mn})$, dan timbal $(\mathrm{Pb})$ yang terkandung dalam tanah selama 100 bulan jika ditangani secara konvensinal seperti saat ini akan terakumulasi seperti tertera pada grafik 4 .

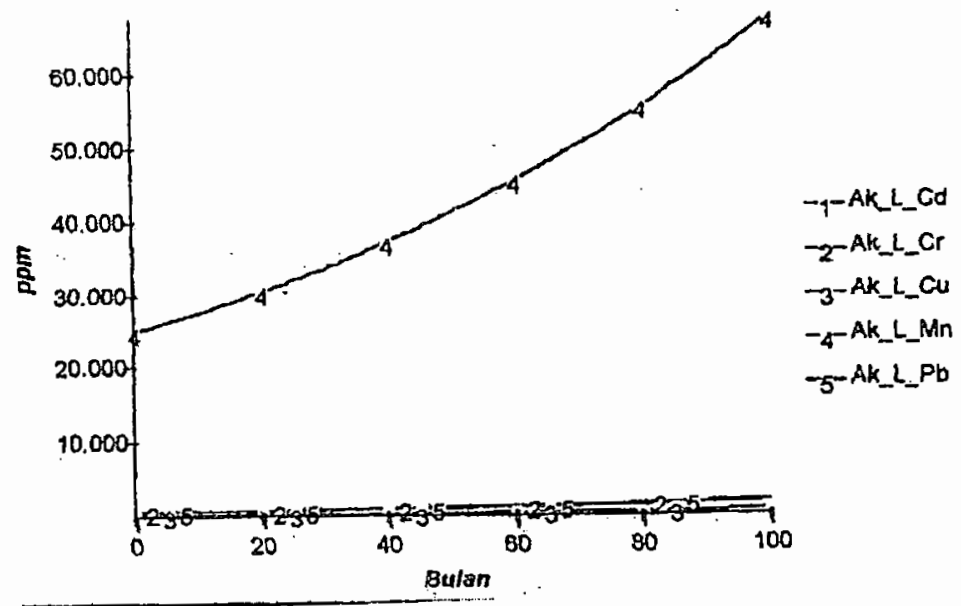

Grafik 4. Jumlah logam berat yang terakumulasi dalam tanah jika limbah tidak diolah. 
Jika simulasi ini dilakukan oleh pihak perusahaan, maka komitment perusahaan untuk mengendalikan pencemaran dengan berbagai usaha termasuk menggunakan bioflokulan yang dianggap dapat mengurangi biaya bahan kimia impor, harus ditegakkan terlebih dahulu, karena jika komitmen belum ada, maka pengolahan limbah tetap akan "diakali" untuk dibuang tanpa melalui proses dan ini berarti akan terjadi kerusakan lingkungan.

Dalam keadaan ini faktor lingkungan dianggap tidak lagi menjadi hal yang penting karena tidak menguntungkan dan malah sebaliknya membuang uang. Untuk mengerjakan hal tersebut, struktur dalam perusahaan, divisi atau personal yang mengurus permasalahan lingkungan seharusnya dibuat tersendiri, sehingga tidak hanya ditempelkan kepada divisi atau personal yang mengurus kegiatan lain, misalnya dibawah divisi atau kepala bagian produksi, dibawah divisi atau kepala bagian maintenance atau bahkan dibawah divisi atau kepala bagian personalia (Sukarsono, 1996).

\section{E. Kesimpulan}

Hasil penelitian ini menunjukkan bahwa pengembangan dari skala pilot ke skala pabrik terdapat berbagai variabel penentu sehingga diperlukan analisis komponen sistem yang saling terkait satu sama lain. Penerapan sistem pengolahan limbah dengan menggunakan bioflokulan Moringa oleifera, secara praktis lebih dapat menguntungkan perusahaan. Namun demikian penerapannya menuntut konskuensi pemenuhan beberapa persyaratan seperti adanya produksi bioflokulan itu sendiri, penanaman dan pengadaan lahannya sekaligus.

Bebarap hal yang harus diperhatikan dalam penerapan skala pabrik, diantaranya:adalah target pertumbuhan produksi, jumlah air yang tersedia, dan sistem pengolahan limbah yang ada saat ini. Faktor-faktor ini akan mempengaruhi dalam penyusunan model.

Hasil simulasi menunjukkan bahwa dengan target pertumbuhan produksi berapapun, lingkungan akan tercemar oleh logam berat, terutama jika penanganannya dilakukan seperti saat ini (mencemari tanah) dimana loga berat (terutama $\mathrm{Mn}$ ) akan terakumulasi dalam julah yang sangat besar. Limbah cair yang bercampur dengan limbah padat seharusnya dilakukan dewatering terlebih 
dahulu untuk kemudian dibuat batako atau dibakar dibuat briket. Kebutuhan Moringa oleifera untuk beberapa pabrik kemungkinan besar dapat dipenuhi hanya dengan memanfaatkan lahan yang cukup kecil namun penanamannya intensif.

\section{Bibliography}

Anonim, 1993, A Guide Book of Powersim, ModelData, Bergen, US.

Crongquist, 1995, An Integreted Syste of Clasification of Flowering Plants, Columbia University Press, New York.

Dahuri, R. dan A. Damar, 1994, Metode dan Teknik Analisis Kualitas Air. Bahan Kuliah Krus Amdal Tipe B, IPB, Bogor.

Dajadiningrat, A.H, 1996, Resources, recovery, dan Program Reduksi Limbah, Seminar Pengelolaan Subersaya Hayati dan Lingkungan Hidup Tropika Menyongsong abad 21, Jurusan Biologi ITB, Bandung.

Dumairy, 1992, Ekonomika Sumberdaya Air : Pengantar Ke Hidrodinaika, BPFE, Yogyakarta.

Edmunds, $\mathrm{S} \&$ Jhon Letey, tt, Environmental Adiministration, Mic Graw Hill Book Company, Toronto.

Gitopadmodjo, L \& W. Winiati, Karakteeristik Limbah Industri tekstil dan Pengenalan Proses dengan Produksi Bersih, Arena Tekstil No.24 1995, 28-29.

Jahn, SAA, 1986. Propoer Use of African Natural Coagulants for rural Water Suplies-Research In Sudan and Guide for New Project, Deutsche Gesellchaft fur Technische Zusaenarbeit (GTZ), Eschborn.

Jorgenses, S.E and I. Johnsen. 1990. Principles of Environmental Science and Technology, Elseiver science Publisher, New York.

Kantor Menteri Negara Lingkungan hidup, 1994. Audit Lingkungan, Jakarta.

Manahan. Stanley E, 1994, Environmental Chemistry; Waste Water Treatment, Lewis Publisher, America

Rahardjanto A, 1998, Efektifitas Bioflokulan Moringa oleifera Lam. Dalam bentuk Memperbaiki Kualitas Fisika-Kimia Air Libah Industri Tekstil, Thesis Pascasarjana ITB, Bandung.

Sukarsono, 1996. Persepsi Pengusaha tentang Audit Lingkungan, Toyota Foundation, Jakarta.

Ulul Albab, Vol. 6 No. 1, 2005 
Kiprah Dr. Yusup Qardhawi dalam Dakwah dan Gerakan Islam serta Pemikirannya tentang Etika Ekonomi

Muhammad Djalfar

Pemasaran Di Perguruan Tinggi

Sugeng Listyo Prabowo -

Pelimpahan Wewenang Ajaran "Hisbah" di Indonesia

M. Nur Asnawi 186

Analisis Model Pengelolaan Zakat

Umrotul Khasanah 197 